\title{
An Archaeological Survey of Walker Ranch Park, Bexar County, Texas
}

Steve A. Tomka

Raba Kistner

Follow this and additional works at: https://scholarworks.sfasu.edu/ita

Part of the American Material Culture Commons, Archaeological Anthropology Commons, Environmental Studies Commons, Other American Studies Commons, Other Arts and Humanities Commons, Other History of Art, Architecture, and Archaeology Commons, and the United States History Commons

Tell us how this article helped you.

This Article is brought to you for free and open access by the Center for Regional Heritage Research at SFA ScholarWorks. It has been accepted for inclusion in Index of Texas Archaeology: Open Access Gray Literature from the Lone Star State by an authorized editor of SFA ScholarWorks. For more information, please contact cdsscholarworks@sfasu.edu. 


\section{An Archaeological Survey of Walker Ranch Park, Bexar County, Texas}

Creative Commons License

(c) (i) (8)

This work is licensed under a Creative Commons Attribution-NonCommercial 4.0 International License 


\title{
An Archaeological Survey of Walker Ranch Park, Bexar County, Texas
}

\author{
Steve A. Tomka
}

Robert J. Hard and C. Britt Bousman

Principal Investigators

Texas Antiquities Permit No. 1903

(C)1998

Center for Archaeological Research The University of Texas at San Antonio Archaeological Survey Report, No. 282 
The following information is provided in accordance with the General Rules of Practice and Procedure, Chapter 41.11 (Investigative Reports), Texas Antiquities Committee:

1. Type of investigation: Survey

2. Project name: Walker Ranch Park

3. County: Bexar

4. Principal investigators: Robert J. Hard and C. Britt Bousman

5. Name and location of sponsoring agency: Parks and Recreation Department, City of San Antonio

6. Texas Antiquities Permit No.: 1903

7. Published by the Center for Archaeological Research, The University of Texas at San Antonio, 6900 N. Loop 1604 W., San Antonio, Texas 78249-0658, 1998

A list of publications offered by the Center for Archaeological Research is available. Call (210) 458-4378; write to the Center for Archaeological Research, The University of Texas at San Antonio, 6900 N. Loop 1604 W., San Antonio, Texas 78249-0658; e-mail to car@lonestar.utsa.edu; or visit CAR's web site at http://www.csbs.utsa.edu/research/car/index.htm. 


\begin{abstract}
The Center for Archaeological Research (CAR) of The University of Texas at San Antonio conducted an intensive surface survey and subsurface testing for cultural resources at the proposed Walker Ranch Park, in northwest San Antonio, Bexar County. Disturbances associated with the park are to include the construction of a parking lot, playground, pavilion, walking/jogging trail, ramps and traffic paths for wheelchair access to the park, and the installation of utility and drainage lines associated with these facilities. The project was carried out under contract with the city of San Antonio Parks and Recreation Department between December 1 and 4, 1997. The project consisted of three tasks: 1) the excavation of 10 backhoe trenches; 2) the excavation of 35 shovel tests, and 3) the intensive pedestrian survey of approximately 4.0 acres of the park.

Buried cultural materials were encountered at a depth of $60-100 \mathrm{~cm}$ below surface (bs) in two backhoe trenches (BHTs 8 and 9) located along Panther Springs Creek. These remains are redeposited and have no potential for archaeological interpretations.

Small numbers of chipped stone flakes were noted primarily in Level $3(20-30 \mathrm{~cm}$ bs $)$ in shovel tests excavated along the north-central and south-central portions of the exercise trail. Widely scattered individual chipped stone artifacts were observed throughout the park. In addition, two small concentrations of historic artifacts and a partially quarried limestone block were identified by the pedestrian survey. The material concentrations have a late nineteenth- to early twentieth-century date range. The partially quarried limestone block probably dates to the mid-nineteenth century.
\end{abstract}

The thin surface scatter of prehistoric artifacts, the shallowly buried specimens, the two historic artifact concentrations, and the partially quarried limestone block are designated as the multicomponent site 41BX1271. CAR recommends that as long as subsurface disturbances are limited to the upper $20 \mathrm{~cm}$ in the north-central and south-central portions of the exercise trail, they will not impact potentially buried components. Deeper subsurface disturbances in other portions of site 41BX1271 at Walker Ranch Park will not adversely affect significant cultural resources. 


\section{Contents}

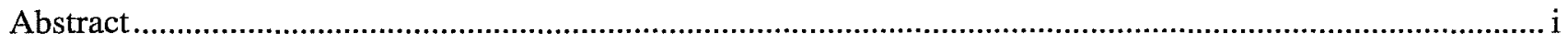

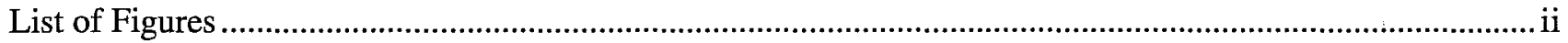

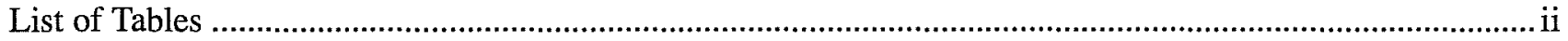

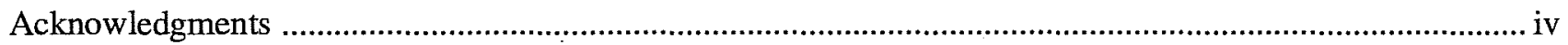

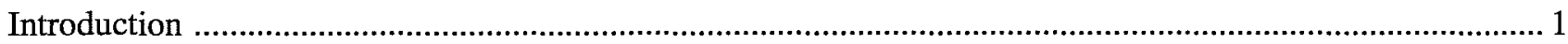

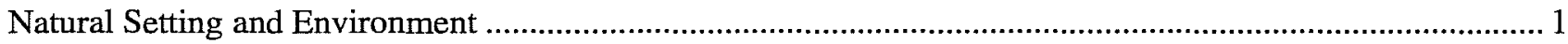

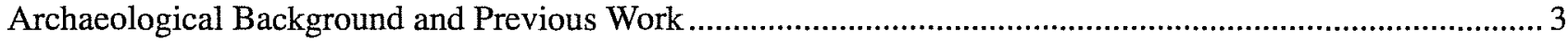

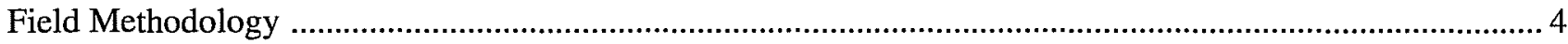

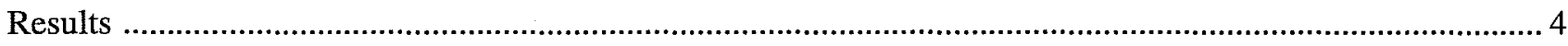

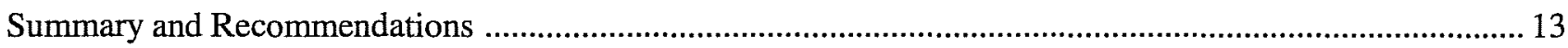

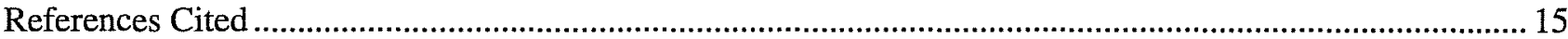

\section{Figures}

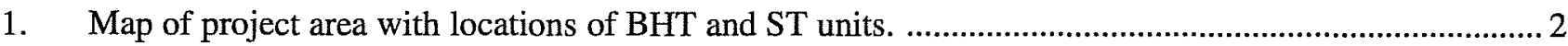

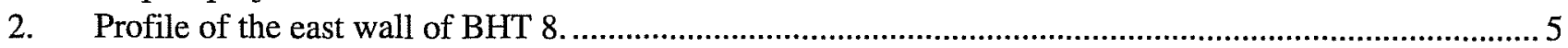

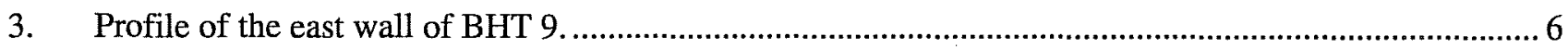

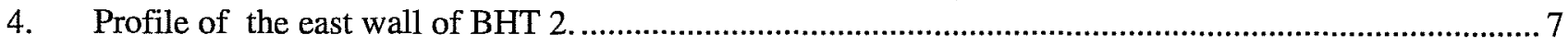

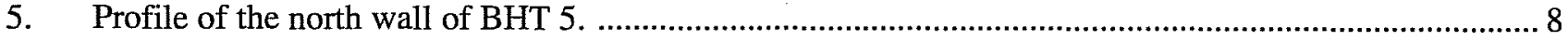

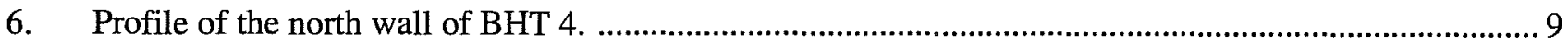

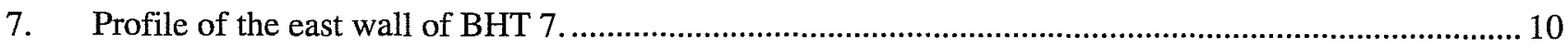

\section{Tables}

1. Numbers and Categories of Artifacts Recovered from Shovel Tests ................................................. 11

2. Numbers and Categories of Artifacts Recovered from Shovel Tests by Level ................................. 12 


\section{Acknowledgments}

The successful completion of this project would not have been possible without the hard work and assistance of Owen Ford, Kevin Hanselka, Richard Jones, and Tony Lyle of the Center for Archaeological Research. Steve Uncapher of the San Antonio Parks and Recreation Department facilitated the project in many ways, not the least of which was providing us detailed project maps. His assistance and friendly demeanor are greatly appreciated. I gratefully acknowledge the support of the CAR staff, in particular director Robert J. Hard, small project coordinator Brett A. Houk, and technical editor Marcie Renner. The figures were drafted by Chris Butler. 



\section{Introduction}

The city of San Antonio contracted the Center for Archaeological Research (CAR) of The University of Texas at San Antonio (UTSA) to identify and record cultural remains that might be affected by the proposed Walker Ranch Park. The property is on a portion of the Walker Ranch located along West Avenue (Figure 1). The project is sponsored by the Parks and Recreation Department of the city of San Antonio, a political subdivision of the state of Texas. An archaeological survey is required at the state level by the Texas Antiquities Code. In addition, the proximity of the project location to Panther Springs and Salado creeks, drainages with numerous and important archaeological sites, reinforces the need for archaeological investigations.

The fieldwork was conducted between December 1 and 4, 1997, by Steve A. Tomka (project director) with Owen Ford, Kevin Hanselka, Richard Jones, and Anthony Lyle, (field archaeologists) assisting. Principal investigator and co-principal investigator were Robert J. Hard and C. Britt Bousman, respectively. Tomka was responsible for report preparation. The project was conducted under Texas Antiquities Permit number 1903, issued by the Texas Historical Commission Department of Antiquities Protection (THCDAP).

The project area is part of Walker Ranch and is located along West Avenue in northwest San Antonio above the confluence of Salado and Panther Springs creeks. The proposed park covers an area of approximately 4.8 acres. The facilities to be constructed along the southern portion of the park include a parking lot, playground, pavilion, and nature path (Figure 1). Entrance to the nature path on the east side of the project area and exit from it along the west end will be provided by ramps cut into the south bank of Panther Springs Creek. The northern two-thirds of the area will contain an exercise trail with two overlooks and a nature trail along the north bank of Panther Springs Creek (Figure 1).

Initial inspection of the proposed park indicated that the southern portion of the area immediately adjacent to West Avenue has been severely impacted by previous construction activities. The visible impacts include a paved driveway along Salado Creek leading to a small paved parking lot located at the planned site of the pavilion. A concrete sidewalk runs west toward a now-razed structure that sat about $70 \mathrm{~m}$ from this lot. A large slab foundation sits in the northeast portion of the planned playground and a beam foundation runs along its southern half. A second concrete slab is found about 75 m east-northeast of the playground's location along the west-central edge of the planned parking lot. A windmill with a large water tank and a swimming pool mark the location of a homestead within the eastern half of the oval exercise trail (Figure 1). The extreme western edge of the exercise trail area has been substantially regraded to provide appropriate facilities for a shooting range (i.e., flat shooting surface and large mound of dirt for backstop).

Subsurface disturbances associated with the construction of the new parking lot, the exercise trail, and the wheelchair-access nature path are not anticipated to be deeper than $20 \mathrm{~cm}$ below surface. The beam foundation located in the heavily disturbed playground area will be removed by excavating to its base. The ramps providing access to and from the nature path along Panther Springs Creek will necessitate subsurface disturbances as deep as $1.75 \mathrm{~m}$ into the banks of the creek (Figure 1). The installation of a drainage line leading from the playground into Salado Creek is anticipated to extend $90 \mathrm{~cm}$ below surface. The removal of the existing paved lots will disturb only the previously laid base.

\section{Natural Setting and Environment}

The project area is located in the southern fringe of the Edwards Plateau Balcones Canyonlands natural subregion of Texas (LBJ School of Public Affairs 1978). The landscape is dissected by numerous highgradient streams in steep-sided canyons that flow south and southeast to the Gulf of Mexico (Riskind and Diamond 1988:1). These streams would have provided ideal locations for prehistoric valley-bottom seasonal camps. 


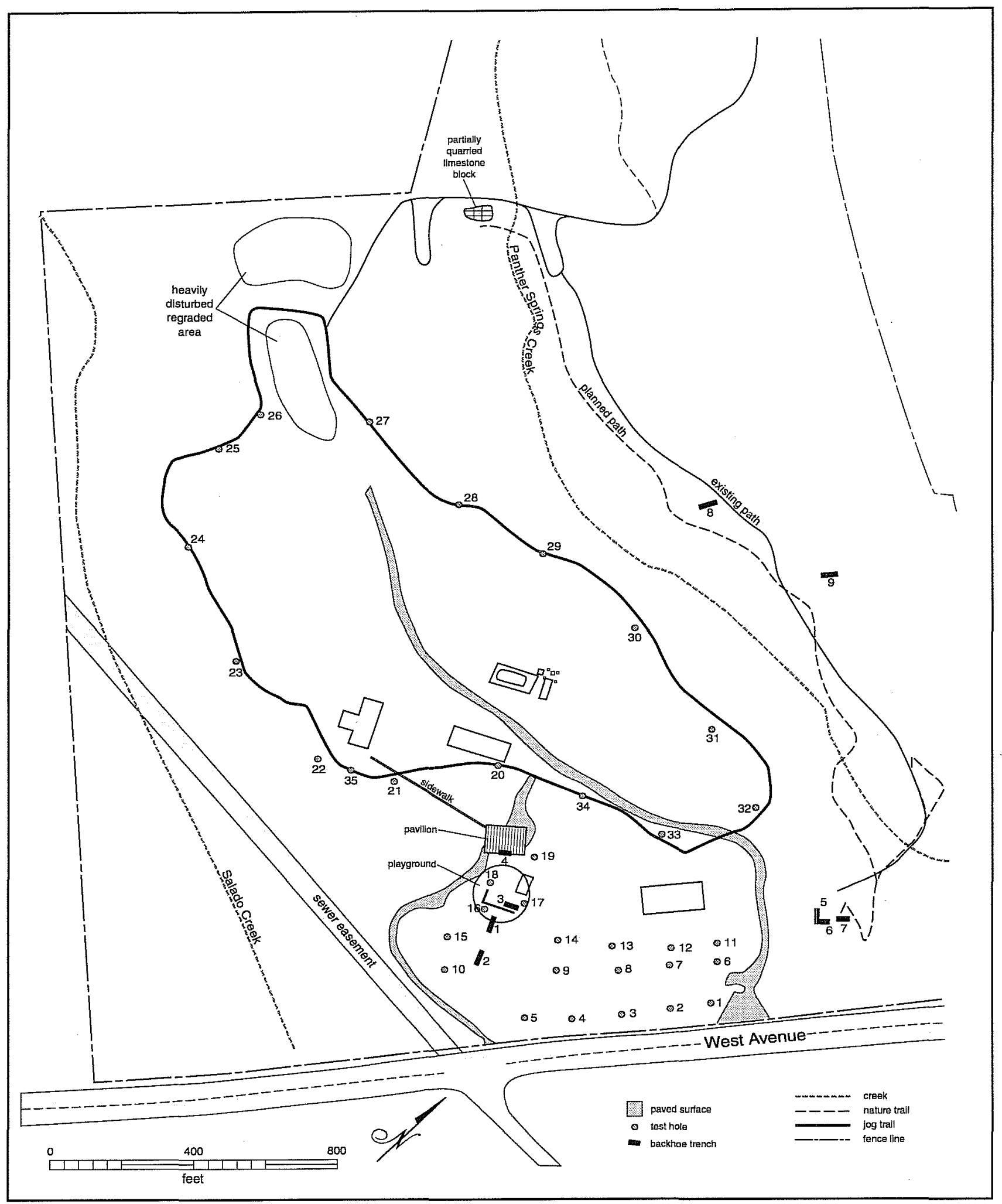

Figure 1. Map of project area with locations of BHT and ST units. 
The present-day vegetation consists of mixed evergreen-deciduous woodlands along the edge of the escarpment, grading into deciduous woodlands then into forest in riparian and deep canyon settings (Van Auken 1988, 1993; Van Auken and Bush 1988). Prior to European settlement, the vegetation setting along the southeastern border of the Edwards Plateau was predominantly grasslands with woodlands and forests limited to hillsides and deeply incised limestone canyons (Weniger 1988). The mixture of grasslands and riparian forests, in addition to the nearby Blackland Prairie, would have provided prehistoric inhabitants of the region with ample game and edible plant resources. A reconstruction of the paleoenvironmental conditions in the Salado Creek watershed, for the period between 2400 B.P. and 5000 B.P., is offered by Katz $(1987: 8,88)$ based on phytolith data obtained by Robinson from 41BX300.

The immediate project area is located within the Upper Salado Creek watershed (Katz 1987; Potter et al. 1995). More specifically, the approximately 4.8 -acre project area is located immediately northwest of West Avenue, above the confluence of Salado and Panther Springs creeks. The soils are part of the TarrantBrackett association (Taylor et al. 1962) and consist of the Lewisville Series silty clays. They are common on terraces above the floodplains of larger creeks and rivers. The solum ranges from $50-150 \mathrm{~cm}$ in depth (Taylor et al. 1962:113) and, as a result, has a strong potential to contain buried components.

\section{Archaeological Background and Previous Work}

Although Bexar County contains one of the largest number of sites excavated in any county in the state, the cultural history and chronology of the area continue to be debated (Black 1989; Collins et al. 1990; Johnson 1995). Nonetheless, archaeological excavations within the county and its vicinity have unearthed remains belonging to all three major time periods identified across the state (Hester 1995): Paleoindian (ca. 11,000-8000 B.P.), Archaic (ca. 8000-1150 B.P.), and Late Prehistoric (ca. 1150-350 B.P.).
The project area itself is located within the NuecesGuadalupe Plain biogeographical area of the South Texas Plain (Black 1989:39-40). Because of the concentration of springs and streams along the Balcones Escarpment, the region has been a favored camping place throughout prehistory (McKinney 1981; Story 1985), and particularly during Hester's (1995) Early Archaic period (see Tomka et al. 1997). Previous work within the Salado Creek watershed and in the broad vicinity of the project area includes archaeological surveys by the Texas Historical Commission (Hudson et al. 1974), the Texas Archeological Salvage Project (Dibble 1979), and more recently, Geo-Marine (Cliff et al. 1990). These surveys resulted in the recording of a large number of residential camps, special activity sites, and lithic procurement localities. Some of these sites have been subsequently tested and excavated (Black and McGraw 1985; Fox 1979; Hudson et al. 1974; Katz 1987; Potter and Black 1995).

In assessing the potential for archaeological remains within the project area, we consider not only the previous work but also broader archaeological patterns and research issues. Recently completed work along the Wurzbach Parkway (Potter et al. 1995) provides a conceptual framework for archaeological studies and a historic context for evaluating sites in the vicinity of the present project area. In addition, a planning document for archaeological work in the Rio Grande and Central Coastal Plains (Tomka et al. 1997) provides a summary of broader archaeological patterns useful in considering the present work.

Prehistoric archaeological sites are common on creek and stream terraces in the Upper and Middle Salado Watershed (Potter et al. 1995:Figure 2) and the Rio Grande Plains in general (Tomka et al. 1997:Figure 4-8). Early Archaic sites are particularly common in these settings (e.g., 41BX184, 41BX198, 41BX271, 41BX300 [Potter et al. 1995; Tomka et al. 1997:Figure 4-9]), while Middle Archaic sites tend to be overrepresented in fossil floodplain settings, such as abandoned channels and oxbow lakes (Tomka et al. 1997:Figure 4-9). Given the clustering of both edible and abiotic resources in valley bottom settings, the archaeological property types expected in the Salado and Panther Springs creeks' drainages could include residential camps, sites with burials, limited activity 
camps, residential and lithic procurement camps, and specialized lithic procurement camps (Tomka et al. 1997:Figure 4-11; Potter et al. 1995:46-51). It is also possible that some aspect of lithic procurement (e.g., early stage reduction of flint nodules), and even residential occupations, would have actually occurred on stabilized gravel bars within the active channels of chert-carrying streams (see Houk and Nickels 1997 for a discussion of 41BX1103). These broader regional patterns, in conjunction with previous archaeological work, reinforce the need for a careful search for archaeological remains along the Leon Creek drainage and similar riverine settings.

\section{Field Methodology}

During a visit to the project area with Steve Uncapher, representative of the San Antonio Parks and Recreation Department, we decided that 10 backhoe trenches would be excavated within the proposed park. The purpose of these backhoe trenches was to explore the nature of deposits in areas where deeper subsurface disturbances related to construction activities (e.g., utility line installation and access ramp construction) were anticipated.

The approximate location of the 10 trenches is shown in Figure 1. The trenches varied from 4-5 $\mathrm{m}$ in length and were approximately $0.75 \mathrm{~m}$ wide. The depth of the trenches ranged from 120-190 cm depending on the anticipated depth of the construction-related disturbance. Following excavation, a one-meter-long representative segment of each trench was profiled and photographed. Soil samples were collected from undisturbed levels within each trench for closer laboratory examination.

In addition, 35 shovel tests were to be excavated within the project area (Figure 1). Nineteen of these were planned within the area defined by the pavilion, playground, and parking lot. Where feasible, these shovel tests were excavated to a depth of $50 \mathrm{~cm}$ below surface. The expected subsurface disturbance was to impact the upper $30 \mathrm{~cm}$ of deposits. Sixteen additional shovel tests were to be excavated along the proposed route of the exercise trail. These were spaced approxi- mately $50 \mathrm{~m}$ apart, except in the northwest portion of the planned trail. No shovel tests were planned in this area due to previous disturbance from heavy grading. These shovel test were not to exceed $30 \mathrm{~cm}$ in depth since anticipated disturbance was to extend only 20 cm below surface (bs).

Finally, an intensive pedestrian survey was to be conducted covering approximately 4.0 acres of previously unsurveyed area within the 4.8 -acre proposed park. This survey was carried out employing $30-\mathrm{m}$ wide transect intervals.

\section{Results}

\section{Backhoe Trenches}

Ten backhoe trenches (BHTs) were excavated in the project area (Figure 1). Three were located along the north bank of Panther Springs Creek and one was excavated along the north bank of Salado Creek. The remainder were positioned on higher ground overlooking the two creeks. Archaeological materials were identified in only two of the 10 trenches (BHTs 8 and 9) along Panther Springs Creek. The remaining trenches provided data on the degree of recent subsurface disturbance in different parts of the proposed park, but contained no cultural materials.

Although the stratigraphy of the two positive BHTs differed somewhat, the artifacts were found in the same gravel layer. Four strata (Zones 1-4) were identified in BHT 8 (Figure 2). Zone 1 is nine centi-meters thick and consists of a dark-gray silt loam (7.5YR 2.5/1) with rootlets and organic material. Zone 2 is a gravel layer with clast-supported clay loam in the intrecies (10YR 7/4). The gravels range in size from granules to pebbles. The zone is $60 \mathrm{~cm}$ thick. The underlying zone (Zone 3 ) is a 38 -cm-thick clay loam layer with infrequent gravels. The gravels range from granules to small pebbles (10 $\mathrm{mm}$ maximum dimension). Four flakes and an early-reduction stage biface were recovered from $60-100 \mathrm{~cm}$ bs at the bottom of Zone 2 and throughout Zone 3 . Zone 4 is found in the bottom $42 \mathrm{~cm}$ of the trench and consists of gravels with clay loam. The gravels range from pebble to cobble size and are rather numerous. 


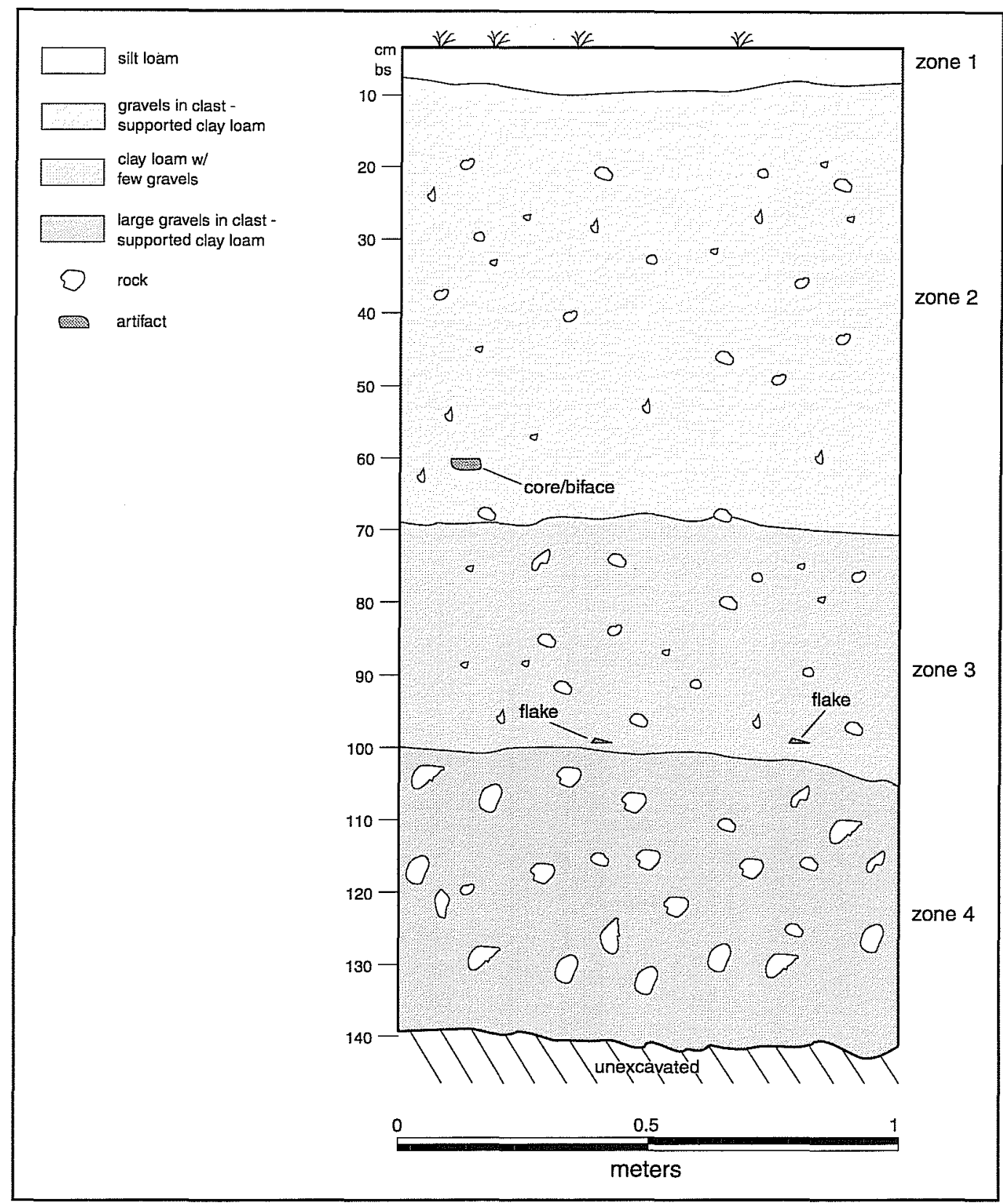

Figure 2. Profile of the east wall of BHT 8.

Four strata (Zones 1-4) were also identified in BHT 9 (Figure 3). Zone 1 consists of a fine-grained yellowish silt $(2.5 \mathrm{Y} 8 / 4)$ that has been recently deposited as a result of sheetwash from an artificial mound of dirt found approximately $50 \mathrm{~m}$ to the north, adjacent to Wurzbach Parkway. This lens ranges from $5-10 \mathrm{~cm}$ in thickness. Underlying this is a silt loam layer (10YR 4/1), Zone 2, which is identical to Zone 1 in BHT 8. It ranges from $23-35 \mathrm{~cm}$ in thickness. Zone 3 , which ranges from $24-30 \mathrm{~cm}$ in thickness, is a silt loam transition zone that is lighter in color (10YR 3/1) than the overlying zone. Small gravels $(<3 \mathrm{~cm}$ in maximum dimension) are more common than in Zone 2. Zone 4 is found in the bottom $70 \mathrm{~cm}$ of the trench and consists of the same gravel layer with clay loam as Zone 4 in BHT 8. Seven flakes were recovered from a depth of $80-100 \mathrm{~cm}$ bs within Zone 4.

The 11 debitage specimens recovered from the two BHTs consist of four secondary flakes and seven tertiary specimens. All of the flakes have severely crushed edges and most even exhibit minute crushing 

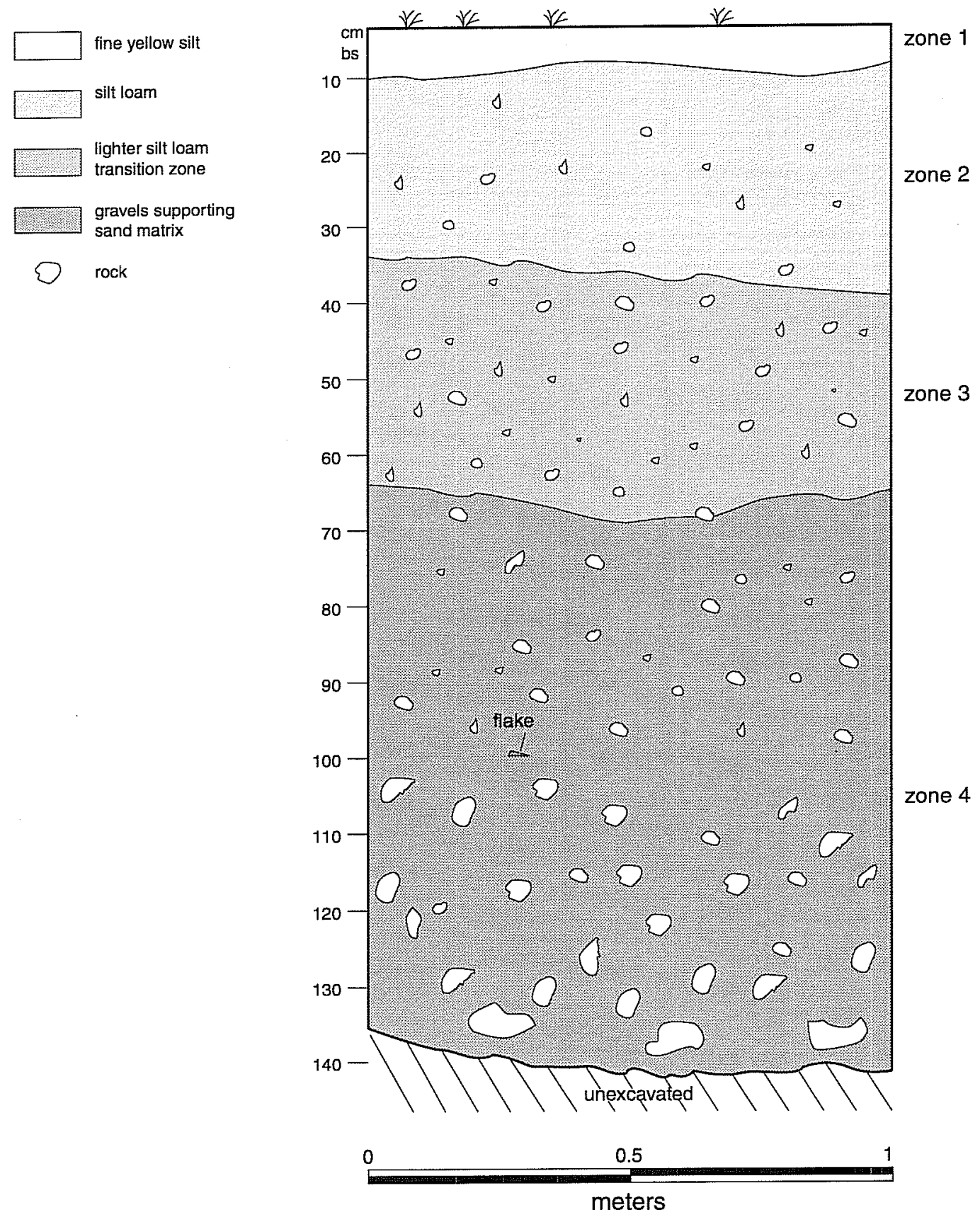

Figure 3. Profile of the east wall of BHT 9.

on multiple dorsal flake scar ridges. The earlyreduction-stage biface exhibits similar crushed edges and dorsal flake scar ridges. These characteristics are indicative of very dynamic post-removal transport and depositional contexts. It is concluded that these artifacts represent secondary deposits lacking associational integrity.
In general, the deposits in the remaining eight backhoe trenches consist of three depositional zones. In portions of the project area not covered by pavement and/or concrete slabs, the upper unit (Zone 1) consists of a thin silt loam layer with modern vegetation. It ranges from $2 \mathrm{~cm}$ thick in BHT 1, (Figure 4) to $30 \mathrm{~cm}$ in BHT 5 (Figure 5). In BHT 4, Zone 1 consists of a 


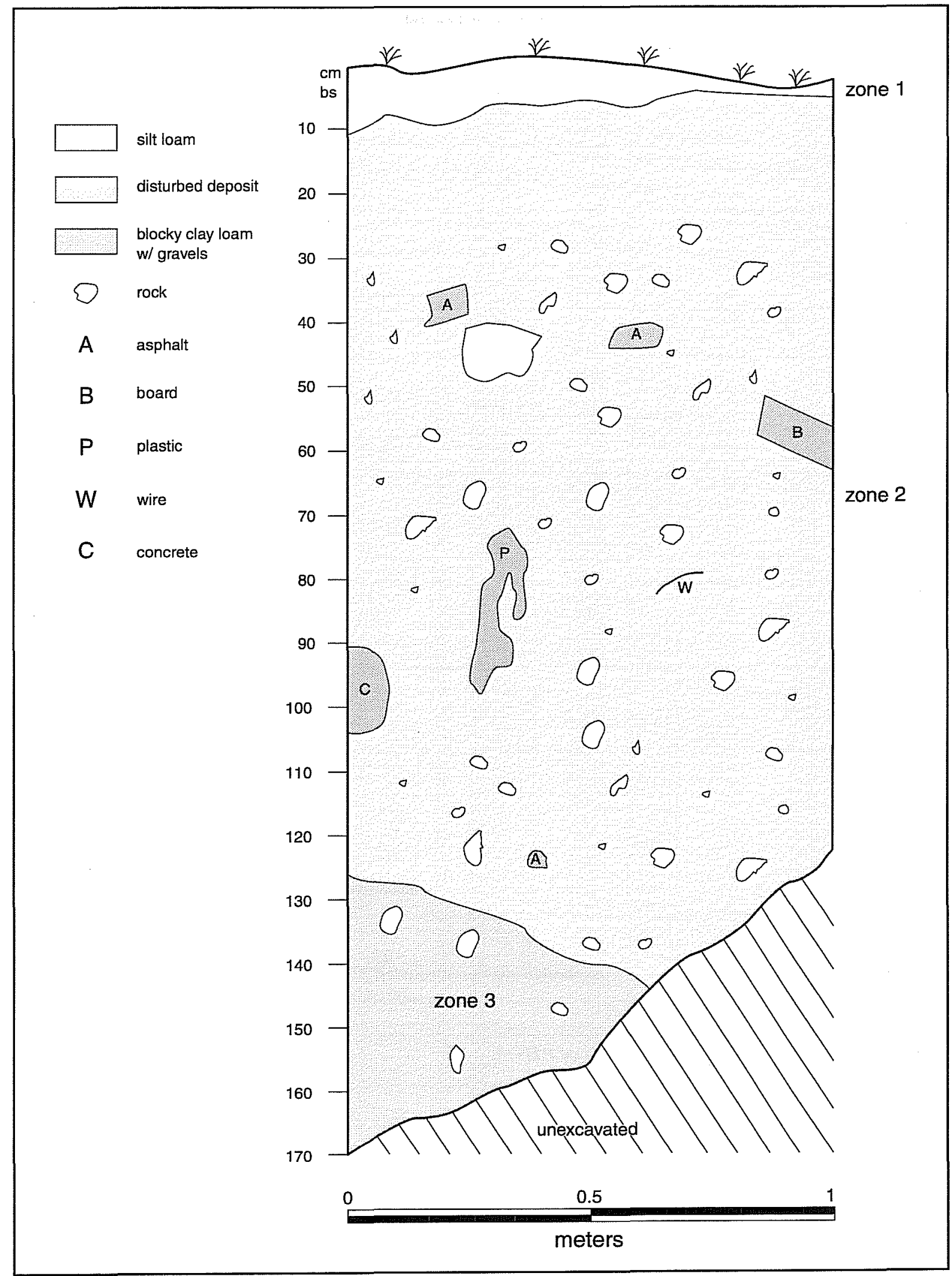

Figure 4. Profile of the east wall of BHT 2. 


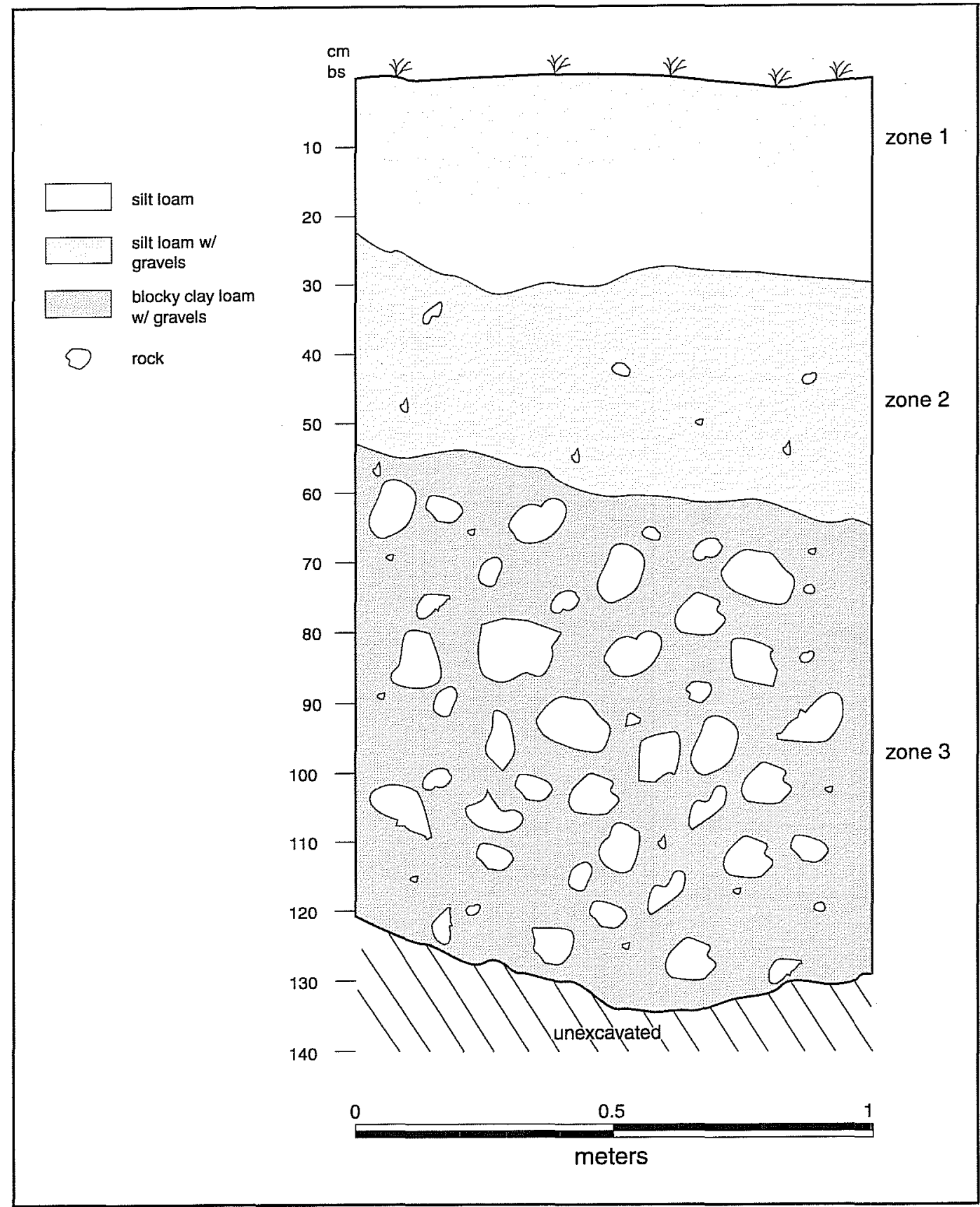

Figure 5. Profile of the north wall of BHT 5.

very compact gravel layer immediately below the asphalt pavement (Figure 6). It varies from $30-35 \mathrm{~cm}$ in thickness and represents an artificially introduced base laid down prior to construction. It is likely that a similar base is present under all other paved areas and concrete slabs found in the southeastern portion of the project area. Consequently, it is likely that the upper $30-35 \mathrm{~cm}$ of deposits are recently introduced materials containing no cultural materials of any significance.

The nature of the second depositional unit (Zone 2) varies across the southern part of the project area. For instance, BHTs 5 and 7 were excavated into one of Panther Springs Creek's terraces (T2). They show that at this location Zone 2 consists of a dark-gray (10YR $2.5 / 2$ ) silt loam layer with gravels. The gravels range 


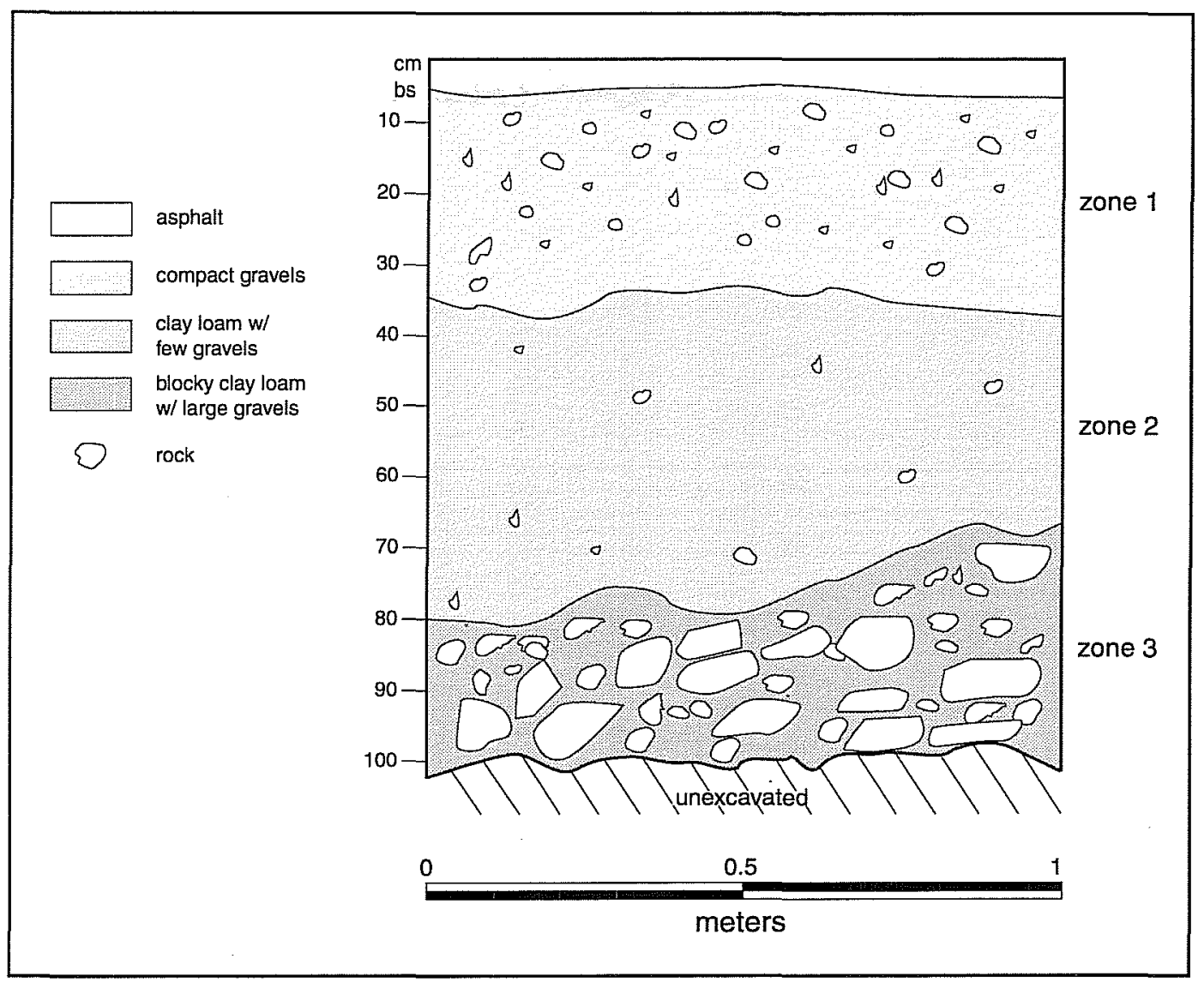

Figure 6. Profile of the north wall of BHT 4.

in size from granules to pebbles. The zone ranges from $30 \mathrm{~cm}$ thick in BHT 5 to $85 \mathrm{~cm}$ BHT 7 (Figures 5 and 7). On the other hand, Zone 2 in BHT 2, excavated into one of Salado Creek's terraces (T2), consists of heavily disturbed deposits (Figure 4). Chunks of concrete and asphalt as well as fragments of wire, plastic tiles, and lumber are common within the zone. The zone ranges from $100-120 \mathrm{~cm}$ in thickness and represents recent fill probably introduced following the demolition of the structures associated with the slab and beam foundations found in the planned playground area (Figure 1). On higher ground and at a greater distance from Salado Creek, Zone 2 consists of undisturbed black clay loam (7.5YR 2.5/1), as exemplified in BHT 4 (Figure 6). It ranges from 28$42 \mathrm{~cm}$ in thickness and contains only granule-size gravels.

The third depositional unit (Zone 3) is undisturbed throughout the southeastern half of the project area. It consists of a reddish brown (7.5YR 3/4) blocky clay loam with oxidized gravels. The quantity and size of the gravels varies from few and small (granules) gravels (BHTs 2 and 7; Figures 4 and 7) to abundant gravels ranging from granules to pebbles in size (BHTs 4 and 5; Figures 5 and 6).

\section{Shovel Tests}

Thirty-five shovel tests (STs) were excavated in the project area (Figure 1). Of these, 15 (STs 1-15) were placed in the parking lot area, three (STs 16-18) were excavated in the proposed playground, and one (ST 19) was positioned on the edge of the future pavilion. When possible, these 19 shovel tests were excavated to $50 \mathrm{~cm}$ bs. The remaining 16 shovel tests (STs 2035) were excavated approximately $50 \mathrm{~m}$ apart along the route of the proposed exercise trail. The planned construction-related disturbance along the exercise trail will be confined to the upper $20 \mathrm{~cm}$ bs, so these shovel tests were excavated to a depth of only $30 \mathrm{~cm}$ bs. 


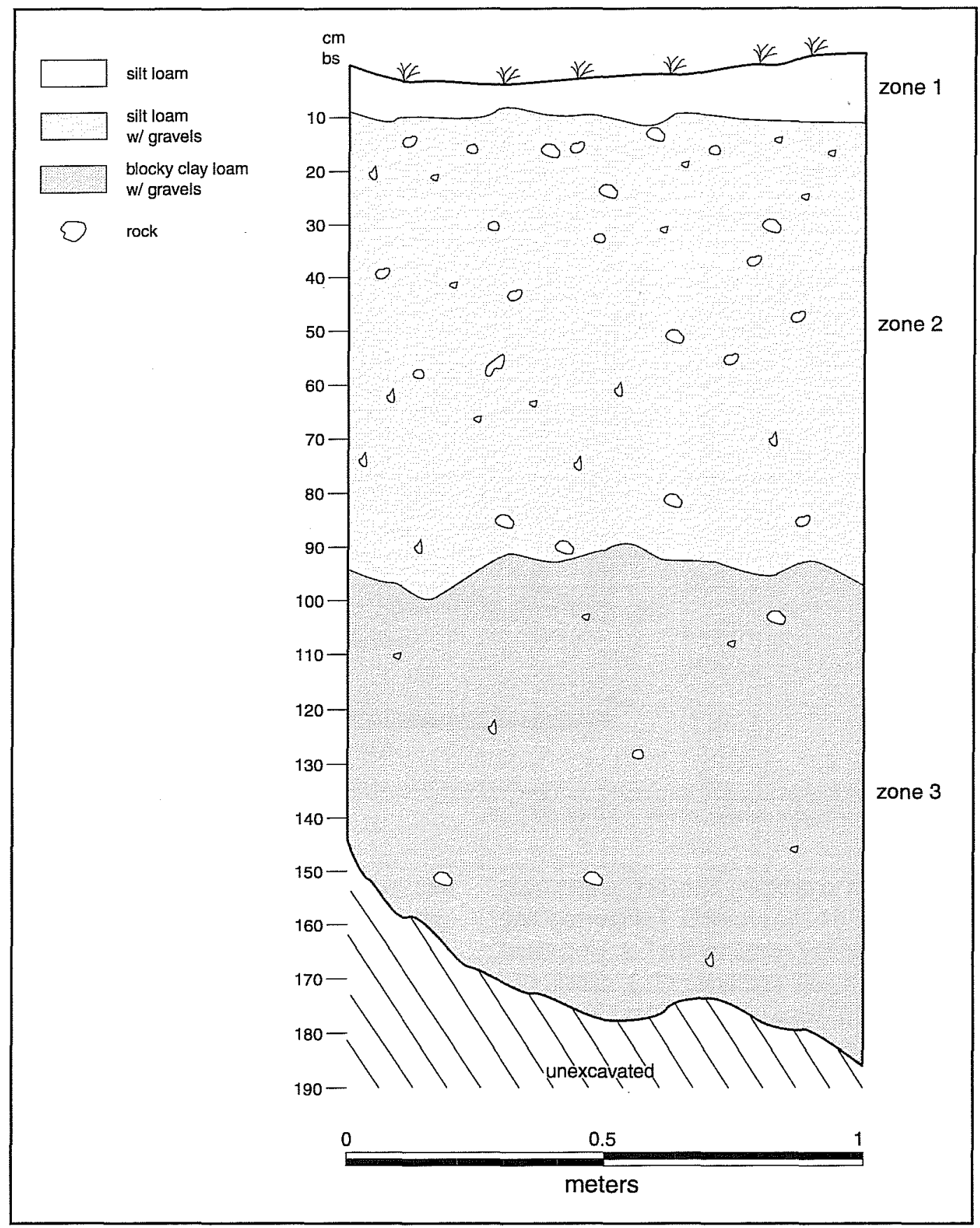

Figure 7. Profile of the east wall of BHT 7.

Twenty (57 percent) of the shovel tests were positive, while 15 (43 percent) yielded no cultural material (see Figure 1). The numbers and categories of artifacts recovered from these shovel tests are shown in Table 1. Construction materials (e.g., glazed sewer tiles, paving tiles, concrete, bricks, asphalt flooring tiles) constitute the largest category, followed by lithics (i.e., chipping debris) and wire nails. Other artifact categories occur in much lower frequencies. The nonlithic items were examined by Anne A. Fox. Although wire nails have been manufactured since approximately 1890 and asphalt floor tiles since the 1940s, taken together the shovel tests did not yield buried pre-1950 cultural material. 
Table 1. Numbers and Categories of Artifacts Recovered from Shovel Tests

\begin{tabular}{|c|c|c|c|c|c|c|c|c|c|c|c|}
\hline ST & 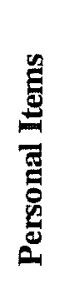 & 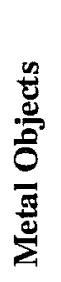 & $\begin{array}{l}\frac{n}{0} \\
\frac{0}{v} \\
\frac{w}{2}\end{array}$ & 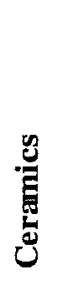 & $\begin{array}{l}\text { 总 } \\
\frac{\mathbf{I}}{\tilde{J}}\end{array}$ & : & 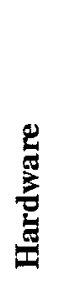 & 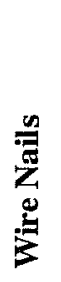 & 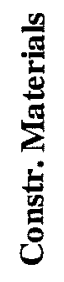 & 总 & 窇 \\
\hline 2 & & & & & & & & 1 & & & 1 \\
\hline 8 & & & & & & & & & & 3 & 3 \\
\hline 9 & & & & & & & & 1 & & & 1 \\
\hline 11 & & & & & & & & 1 & 28 & & 29 \\
\hline 16 & & & & & & & & & 3 & & 3 \\
\hline 17 & 3 & & & & 5 & & 2 & 1 & 16 & 1 & 28 \\
\hline 18 & & & & & 1 & & 1 & & & & 2 \\
\hline 20 & & & & & & & & 2 & & & 2 \\
\hline 21 & & & & & & & & & & 7 & 7 \\
\hline 22 & & & & & & & & & & 4 & 4 \\
\hline 23 & & & & & & & & & & 1 & 1 \\
\hline 24 & & & & & & & & & & 1 & 1 \\
\hline 28 & & & & & & & & & & 5 & 5 \\
\hline 29 & & & & & & & & & & 1 & 1 \\
\hline 30 & & & & & & & 2 & 12 & & & 14 \\
\hline 31 & & 6 & 2 & & & & 1 & & & 5 & 14 \\
\hline 32 & & & & & & & 1 & 1 & & & 2 \\
\hline 33 & & 1 & & & 3 & & & & & & 4 \\
\hline 34 & & & & 2 & & & & & & & 2 \\
\hline 35 & & & & & 2 & 1 & & & & 1 & 4 \\
\hline Totals & 3 & 7 & 2 & 2 & 11 & 1 & 7 & 19 & 47 & 29 & 128 \\
\hline
\end{tabular}

The distribution of the 128 artifacts by level is shown in Table 2. The majority of the artifacts come from Levels 1-3. In general, recent artifacts tend to decrease by level while lithic debris tends to increase with depth. The recent artifacts most likely represent construction and habitation debris derived from post-1960s utilization of the southeastern portion of the proposed park in the vicinity of West Avenue. The lithic artifacts constitute prehistoric or historic period chipping debris. All of the specimens are flakes, flake fragments, and heat spalls derived from chipped lithic artifacts. No temporally diagnostic artifacts were encountered.
While the majority of shovel tests yielded 1-3 lithics, four units contained four or more specimens. Two of these units (STs 21 and 22) are adjacent to each other and are found on the southern edge of the exercise trail (Figure 1). The other two are along the north (ST 28) and northeastern (ST 31) edge of the trail separated by approximately 150 meters (Figure 1 ). Of the 21 flakes recovered within these four shovel tests, 13 (62 percent) are from Level 3, 5 (24 percent) are from Level 2, and 3 (14 percent) are from Level 1. This pattern indicates that the lithic artifacts tend to cluster in the gravely dark-gray clay loam matrix characteristic of undisturbed portions of higher ground in the park 
Table 2. Numbers and Categories of Artifacts Recovered from Shovel Tests by Level

\begin{tabular}{|c|c|c|c|c|c|c|c|c|c|c|c|}
\hline $\begin{array}{l}\bar{\Phi} \\
\overline{9}\end{array}$ & 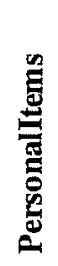 & 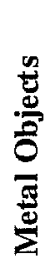 & 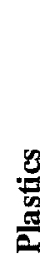 & 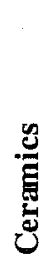 & $\begin{array}{l}\frac{w}{\omega} \\
\frac{\omega}{\omega t}\end{array}$ & $\stackrel{\mathscr{g}}{0}$ & 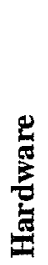 & 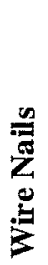 & 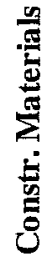 & 总 & $\frac{n}{0}$ \\
\hline 1 & 2 & 6 & & 2 & 5 & & 3 & 10 & 19 & 5 & 52 \\
\hline 2 & 1 & 1 & 2 & & 4 & & 4 & 6 & 15 & 9 & 42 \\
\hline 3 & & & & & 2 & 1 & & 2 & 12 & 15 & 32 \\
\hline 4 & & & & & & & & 1 & 1 & & 2 \\
\hline Totals & 3 & 7 & 2 & 2 & 11 & 1 & 7 & 19 & 47 & 29 & 128 \\
\hline
\end{tabular}

(see Figure 6, Zone 2, BHT 4). It is possible that a low-density archaeological component is buried at a depth of $20 \mathrm{~cm}$ and below, in the vicinity of these four shovel tests.

\section{Pedestrian Survey}

Eighteen equally spaced transects were walked during the survey. The transects were parallel to West Avenue and began on the southeast at Panther Springs Creek and ended on the northwest at Salado Creek. Eleven isolated prehistoric lithic artifacts were observed during the survey: five early- to middle-reduction-stage bifaces, four multidirectional cores, and two large secondary flake cores. They appear to represent the products of intermittent lithic procurement in an area characterized by small quantities of chert.

Three historic features were recognized during the pedestrian survey (Figure 1). They consists of two small artifact concentrations and a partially quarried limestone block. One of the concentrations is located $15 \mathrm{~m}$ west of BHTs 5 and 6 , and the other about $30 \mathrm{~m}$ north of ST 27. They contain sewer tile fragments, porcelain plumbing fixtures, glass bottle and jar fragments, and ironstone bowl and hotel china fragments. Fox's examination of the first of these concentrations indicates a late nineteenth- to early twentieth-century date range. The small concentrations represent dumps of artifacts derived from unknown locations or perhaps previously standing structures in the project area.

The partially quarried limestone block is located in the bed of Panther Springs Creek at the northwest end of the project area (Figure 8). An old quarry, used in the mid-nineteenth century, is located near the North Loop Road crossing of Salado Creek, southeast of the project area (Fox 1979:3). Although the large grooved but uncut block could derive from this quarry, it appears to be in situ bedrock, not a block that has been transported to and discarded at this location. Although the year in which the stone was quarried cannot be established by independent means, the activity may have occurred sometime during the period when the nearby quarry was in use. The block measures $3.0 \mathrm{x}$ $2.5 \mathrm{~m}$ and has four quarry grooves that were intended to yield three ca. $1-\mathrm{x}-1-\mathrm{m}$ blocks and at least three more ca. $0.5-\mathrm{x}-1-\mathrm{m}$ blocks.

\section{BX1271}

The thin scatter of prehistoric artifacts found throughout the entire project area and the three historic features are designated site $41 \mathrm{BX} 1271$. The site sits on the interfluve between Salado and Panther Springs creeks, immediately west-northwest of West Avenue. It measures roughly $500 \times 150 \mathrm{~m}$ and is multicomponent. The prehistoric component appears to represent the intermittent use of the area for lithic 
procurement. Prehistoric cultural material (i.e., flakes) extend to a depth of $40 \mathrm{~cm}$ bs. No temporal diagnostics were recovered. The historic component consists of two isolated artifact concentrations and a partially quarried limestone block. The block might be contemporaneous with the nearby mid-nineteenth-century quarry while the artifact concentrations date to the later part of the century or later.

\section{Summary and Recommendations}

Between December 1 and 4, 1997, CAR personnel conducted an intensive surface survey and subsurface testing for cultural resources at the proposed Walker Ranch Park, in Northwest San Antonio, Bexar County. The project area is located immediately northwest of West Avenue and the confluence of Panther Springs and Salado creeks. The project consisted of the excavation of 10 backhoe trenches and 35 shovel tests, and the intensive pedestrian survey of approximately 4.0 acres of the 4.8 -acre park.

The project resulted in the identification of $41 \mathrm{BX} 1271$, a large but light multicomponent site encompassing much of the project area. It contains historic and prehistoric components, with artifacts from both components being found on surface and in buried contexts.

Buried prehistoric cultural materials (i.e., flakes) were identified in two of the backhoe trenches (BHTs 8 and 9) along Panther Springs Creek. Although these remains were encountered between $60-100 \mathrm{~cm}$ bs, given their obvious secondary context, they are judged to have no associational integrity and very limited interpretive potential.

The majority of the 35 shovel tests yielded between one and three lithic artifacts. No temporally diagnostic speci-mens were recovered. Four shovel tests contained four or more specimens. Two of these units (STs 21 and 22) are found along the southern edge of the exercise trail (Figure 1), while the other two are along the north (ST 28) and northeastern (ST 31) edge (Figure 1), respectively. The highest density of artifacts occurs in Level 3, at a depth of $20-30 \mathrm{~cm}$ bs. Given the possibility that a low-density archaeological com- ponent is found at this depth, we recommended that subsurface disturbances should not extend below 20 $\mathrm{cm}$ in the vicinity of these four shovel tests. We also recommend that further testing be carried out at $41 \mathrm{BX} 1271$ if deeper disturbance of these areas is necessary.

The pedestrian survey of the proposed park located a total of 11 prehistoric artifacts: six cores and five earlyto middle-reduction-stage rejected bifaces. The artifacts represent the by-products of intermittent lithic procurement in an area characterized by small quantities of widely dispersed raw material resources. Since none of these artifacts are temporally diagnostic, activities related to park construction and use are judged to impact only prehistoric surface artifacts of very limited interpretive potential.

The 35 shovel tests also yielded a number of modern artifacts. Fox's analysis indicates that none of these items date prior to 1950 . Two small and thin scatters of historic artifacts identified during the pedestrian survey appear to represent dumps derived from unknown location(s) or from previously standing structures somewhere in the project area. Fox's examination of the materials in one of these concentrations indicates a late nineteenth- to early twentiethcentury date range. The materials noted in the second concentration seem to be of similar or later age. Given the unknown derivation of these dumps and the lack of association with a known household and/or structure, the interpretive potential of these historic artifacts is severely limited.

The partially quarried limestone block at the northwest end of the project area in the bed of Panther Springs Creek is located near the point at which the proposed wheelchair trail crosses the creek. This feature could be incorporated into the proposed park as a link of the area to its recent history. Such exhibits, however, are often subject to vandalism and face high risk of destruction. To avoid attracting too much attention to the block, and yet make it available to the public, we propose shielding it from the direct view of passersby with medium-height shrubs. With the exception of this protective measure in the case of the historic partially quarried block, it is our opinion that any activities associated with the construction, maintenance, and use 
of the proposed park is assumed to impact historic surface artifacts of limited interpretive potential.

Given the limited interpretive potential of the historic and prehistoric components encountered at $41 \mathrm{BX} 1271$, CAR recommends that the sponsor proceed as planned without additional investigations. If subsurface disturbances deeper than $20 \mathrm{~cm}$ bs are necessary in the vicinity of STs $21,22,28$, and 31 , along the proposed exercise trail, we recommended that additional archaeological testing be conducted prior to construction. We commend the San Antonio Parks and Recreation Department for their responsible efforts to identify and protect cultural resources which may be adversely affected by their construction efforts in an area with such high potential for buried archaeological remains. 


\section{References Cited}

Black, S. L.

1989 South Texas Plains. In From the Gulf Coast to the Rio Grande: Human Adaptation in Central, South, and Lower Pecos Texas, by T. R. Hester, S. L. Black, B. W. Olive, A. A. Fox, K. Reinhart, and L. C. Bement, pp. 39-62. Research Series No. 33. Arkansas Archeological Survey, Fayetteville.

Black, S. L., and A. J. McGraw

1985 The Panther Springs Creek Site: Cultural Change and Continuity within the Upper Salado Creek Watershed, South-Central Texas. Archaeological Survey Report, No. 100. Center for Archaeological Research, University of Texas at San Antonio.

Cliff, M. B., M. E. Brown, D. E. Peter, and S. N. Allday

1990 Cultural Resources Survey Along Salado Creek, Bexar County, Texas. Miscellaneous Report of Investigations, No. 17. Geo-Marine, Plano, Texas.

Collins, M. B., B. B. Ellis, and C. Dodt-Ellis

1990 Excavations at the Camp Pearl Wheat Site (41KR243): An Early Archaic Campsite on Town Creek, Kerr County, Texas. Studies in Archaeology 6. Texas Archeological Research Laboratory, The University of Texas at Austin.

Dibble, D. S.

1979 Archeological Reconnaissance in the Salado Creek Watershed, Bexar County, Texas. Survey Report 9. Texas Archeological Salvage Project, The University of Texas at Austin.

Fox, A. A.

1979 Archaeological and Historical Investigations at 41BX180, Walker Ranch, San Antonio, Texas: Phase I. Archaeological Survey Report, No. 83. Center for Archaeological Research, The University of Texas at San Antonio.

Hester, T. R.

1995 The Prehistory of South Texas. Bulletin of the Texas Archeological Society 66:427-460.

Hudson, W. R., W. M. Lynn, and D. Scurlock

1974 Walker Ranch: An Archeological Reconnaissance and Excavations in Northern Bexar County, Texas. Office of the State Archeologist, Report 26. Texas Historical Commission, Austin.

Houk, B. A., and D. L. Nickels (editors)

1997 Phase II Archaeological Investigations at Lackland Air Force Base, San Antonio, Texas. Archaeological Survey Report, No. 264. Center for Archaeological Research, The University of Texas at San Antonio.

Johnson, L.

1995 Past Cultures and Climates at Jones Terrace, 41ME29, Medina County, Texas. Office of the State Archeologist, Report 40.Texas Department of Transportation and Texas Historical Commission, Austin. 
Katz, P. R.

1987 Archaeological Mitigation at 41BX300, Salado Creek Watershed, South-Central Texas. Archaeological Survey Report, No. 130. Center for Archaeological Research, The University of Texas at San Antonio.

LBJ School of Public Affairs

1978 Preserving Texas' Natural Heritage. LBJ School of Public Affairs, Report 31. Austin.

McKinney, W. W.

1981 Early Holocene Adaptations in Central and Southwest Texas: The Problem of the Paleoindian-Early Archaic Transition. Bulletin of the Texas Archeological Society 52:91-120.

Potter, D. R., and S. L. Black

1995 Archeology Along the Wurzbach Parkway Module 2 Initial Testing and Evaluation of Five Prehistoric Sites in the Upper Salado Watershed, Bexar County, Texas. Studies in Archeology 18. Texas Archeological Research Laboratory, The University of Texas at Austin.

Potter, D. R., S. L. Black, and K. Jolly

1995 Archeology Along the Wurzbach Parkway Module 1 Introduction, Conceptual Framework, and Contexts of Archeological Investigations in Bexar County, South-Central Texas. Studies in Archeology 17. Texas Archeological Research Laboratory, The University of Texas at Austin.

Riskind, D. H., and D. D. Diamond

1988 An Introduction to Environment and Vegetation. In Edwards Plateau Vegetation: Plant Ecological Studies in Central Texas, edited by B. B. Amos and F. R. Gehlbach, pp. 1-16. Baylor University Press, Waco.

Story, D. A.

1985 Adaptive Strategies of Archaic Cultures of the West Gulf Coast Plain. In Prehistoric Food Production in North America, edited by R. I. Ford, pp. 19-56. Anthropological Papers No. 75. Museum of Anthropology, University of Michigan, Ann Arbor.

Taylor, F. B., R. B. Hailey, and D. L. Richmond

1962 Soil Survey of Bexar County, Texas. United States Department of Agriculture, Soil Conservation Service.

Tomka, S. A., T. K. Perttula, and R. J. Hard

1997 Archaeology of the Rio Grande and Central Coastal Plains, Texas: A Planning Document. Archaeological Survey Report, No. 266. Center for Archaeological Research, The University of Texas at San Antonio.

Van Auken, O. W.

1988 Woody Vegetation of the Southern Escarpment and Plateau. In Edwards Plateau Vegetation: Plant Ecological Studies in Central Texas, edited by B. B. Amos and F. R. Gehlbach, pp. 43-55. Baylor University Press, Waco, Texas.

1993 Size Distribution Patterns and Potential Population Change of Some Dominant Woody Species of the Edwards Plateau Region of Texas. The Texas Journal of Science 45(3):199-210. 
Van Auken, O. W., and J. K. Bush

1988 Dynamics of Establishment, Growth, and Development of Black Willow and Cottonwood in the San Antonio River Forest. The Texas Journal of Science 40(3):269-277.

Weniger, D.

1988 Vegetation Before 1969. In Edwards Plateau Vegetation: Plant Ecological Studies in Central Texas, edited by B. B. Amos and F. R. Gehlbach, pp. 17-23. Baylor University Press, Waco, Texas. 
